\title{
Genetic Variation Patterns for the Selection of Elite Genotypes in Cultivated Okra (Abelmoschus esculentus (L.) Moench)
}

\author{
Sonia Sood, Nivedita Gupta* and Deepti Sharma \\ Department of Vegetable Science and Floriculture, CSK Himachal Pradesh Krishi \\ Vishvavidyalaya, Palampur, Himachal Pradesh-176 062, India \\ *Corresponding author
}

\begin{tabular}{|l|}
\hline Ke y w o r d s \\
Mean performance, \\
$\begin{array}{l}\text { Genetic parameters, } \\
\text { Correlation, } \\
\text { Quantitative traits, } \\
\text { Quality traits }\end{array}$ \\
\hline Article Info \\
\hline $\begin{array}{l}\text { Accepted: } \\
12 \text { August } 2018 \\
\text { Available Online: } \\
\text { 10 September } 2018\end{array}$ \\
\hline
\end{tabular}

\section{Introduction}

Okra [Abelmoschus esculentus (L.) Moench.] is a Dicotyledonae, belonging to the order Malvales, member of the family Malvaceae and genus Abelmoschus (syn. Hibiscus) grown in kharif and zaid seasons. It is an important vegetable crop grown in tropical and subtropical regions of the world, grown successfully both in the plains and hills
In this research, thirty-seven okra (Abelmoschus esculentus (L.) Moench) accessions selected from different eco-geographical regions of India were evaluated during two years $(2011,2012)$ for genetic variability, heritability and genetic association among fruit yield, quality and agronomical traits in randomized complete block design (RCBD) with three replications. The estimation of phenotypic coefficient of variability (PCV) and genotypic coefficient of variability (GCV) were high for dry matter, mucilage and mineral content. There was high \% broad sense heritability and genetic advance in traits such as internodal length, dry matter, mucilage and mineral content suggesting the effect of additive genes for their inheritance and reliability of selection based on phenotype of these traits for crop improvement. Moderate to low heritability with low genetic advance was recorded for days to $50 \%$ flowering, average fruit weight, days to $50 \%$ emergence, days to first picking, fruit yield/plant, fruits/plant, first fruit producing node and nodes/plant, indicating the nonadditive gene activity. The positive and significant phenotypic and genotypic association studies revealed that the selection based on fruits/plant, average fruit weight and nodes/plant would be fruitful and rewarding for effective improvement of fruit yield in okra. The genotypes (VRH-2XVRO-6)-1-1-2-1, (VRH-2XVRO-6)-9-2-1-3, Hissar Unnat, (IC-169469-1XPK)-1-2-1-2 and Parbhani Kranti were found to be promising for marketable fruit yield/plant along with other desirable quantitative and quality traits revealing thereby these genotypes can be directly used after multi-location testing.
(Tindall, 1983). Its green edible fruits are consumed for vegetable purpose. It is predominantly a self-fertilized crop but natural crossing to the extent of $6.75 \%$ has been reported. It is an interesting crop to breeders and the geneticists, for its mono-adelphous condition of the stamens and large flowers are amendable to easy emasculation and its capsule bears large number of seeds. Being a short duration crop two generations can be 
grown in one year. To improve yield and other characters, information on genetic variability is of great importance and is a prerequisite for the effective screening of superior genotypes.

Generally the success of any crop improvement program largely depends upon the magnitude of genetic variability, genetic advance and character association. Genetic diversity is important for selection of parents to recover transgressive segregants (Kiran Patro and Ravisankar, 2004). Heritability estimates provide information on the proportion of phenotypic variance that is due to genetic factors for different traits, but heritability estimate alone is not a sufficient measure of the level of possible genetic progress that are not even when the most outstanding individuals are selected in a breeding programme. Effective selection can be made when the value of broad sense heritability estimates is considered together with the selection differential or genetic advance (Ibrahim \& Hussein, 2006).

The progress in breeding for economic characters that are mostly environmentally influenced is determined by the magnitude and nature of their genetic variability. Hence, it is essential to partition the overall variability into its heritable and non-heritable components with the help of genetic parameters like genetic co-efficient of variation, heritability and genetic advance. Information on the amount and direction of association between yield and yield-related traits is important for rapid progression selection and genetic improvement of a crop (Asish et al., 2008). This will indicate the interrelationship between two or more plant characters and yield, providing suitable means for indirect selection for yield. This study is aimed to determine which of traits associated with fruit yield in okra have high heritability and high genetic advance so that they can be used for indirect selection to improve okra fruit yield.

\section{Materials and Methods}

The current experiment was conducted at the vegetable experimental farm of CSK Himachal Pradesh Krishi Vishvavidyalaya, Palampur, Himachal Pradesh, India, during 2011 and 2012. The experimental site was located at $32^{\circ} 6^{\prime} \mathrm{N}$ and $76^{\circ} 3^{\prime} \mathrm{E}$, with a mean elevation of $1290.8 \mathrm{~m}$ above sea level. The soil was silt clay loam with 5-5.6 pH and high in organic matter $(1.63 \%)$, total nitrogen (262 $\left.\mathrm{kg} \mathrm{ha}^{-1}\right)$ and available $\mathrm{K}\left(159 \mathrm{~kg} \mathrm{ha}^{-1}\right)$. The site falls under the sub-temperate zone with high rainfall $(2500 \mathrm{~mm})$ and has mean temperatures of $31^{\circ} \mathrm{C}$ (summer) and $13.6^{\circ} \mathrm{C}$ (winters). Fifteen genotypes of okra collected from different eco-geographical regions of the country and twenty-two advance lines were sown in a randomized complete block design (RCBD) with three replications.

Each replication consisted of 4 single rows of each genotype. Each row was $3 \mathrm{~m}$ long with intra-row spacing $45 \mathrm{~cm}$ and inter-row spacing of $15 \mathrm{~cm}$. Each row contained 20 plants. Total compost (10 t/ha) was applied during land preparation. Urea, single super phosphate and murate of potash were applied at 150, 315 and $90 \mathrm{~kg} / \mathrm{ha}$ respectively. Appropriate cultural practices were also maintained. Thinning was done to maintain appropriate plant density within rows. Irrigation was provided at 5-7 days interval during summer period.

\section{Data collection}

Data was collected on 10 randomly selected plants in each replication for various quantitative (days to $50 \%$ emergence, days to $50 \%$ picking, harvest duration (days), plant height $(\mathrm{cm})$, fruit yield/plant $(\mathrm{g})$, fruits/plant, average fruit weight $(\mathrm{g})$, first fruit producing node, internodal length $(\mathrm{cm})$, fruit length $(\mathrm{cm})$ and fruit diameter $(\mathrm{cm})$; and quality traits (dry matter(\%), mucilage (\%) and mineral content $(\mathrm{mg} / \mathrm{kg}))$. 


\section{Quantitative traits}

Days to $50 \%$ emergence: Days from date of sowing to the date when $50 \%$ of seedlings emerged in each entry in each replication were counted.

Days to $50 \%$ flowering: Days from date of sowing to the date when $50 \%$ of flowering occurs in each entry in each replication were counted.

Days to first picking: Number of days from date of sowing to the first harvest in each entry/replication was counted.

Harvest duration (days): Days from first picking to final picking were calculated to estimate harvest duration.

Plant height $(\mathrm{cm})$ : Measured from ground level to top of main shoot after the last picking.

Fruit yield/plant (g): Weight of harvested marketable fruits from each plant in all pickings were recorded and mean values were worked out to find fruit yield/plant.

Fruits/plant: Total number of marketable fruits/plant over all pickings in each replication was recorded.

Average fruit weight (g): Estimated by dividing total weight of fruits with total number of fruits harvested over all pickings. First fruit producing node: Counted from the base to the node at which first fruit set occurs.

Nodes/plant: Nodes/plant was counted at the time of final picking from the base of the plant to tip in each entry/ replication.

Internodal length $(\mathrm{cm})$ : It was calculated by dividing plant height with total number of nodes.
Fruit length $(\mathrm{cm})$ : Ten fruits taken randomly were measured from proximal to distal end of fruit on $4^{\text {th }}$ and $8^{\text {th }}$ picking and average was worked out.

Fruit diameter $(\mathrm{cm})$ : Measured by vernier calliper from mid portion and average was calculated.

\section{Quality traits}

\section{Dry matter $(\%)$}

Estimated by procedure of Arora et al., (2008). 50g of immature fruit samples of each replication/entry was cut and added in preweighed empty petridishes separately. It was taken in oven at a temperature of $60^{\circ} \mathrm{C}$ for duration of 48 hours. Thereafter, the samples were taken out and petridishes were again weighed.

Dry matter (\%): $\frac{\mathrm{W}_{2}-\mathrm{W}_{1}}{-------}$ X 100

$\mathrm{W}_{2}=$ weight of dried sample + weight of empty petridishes ( $\mathrm{g}$ )

$\mathrm{W}_{1}=$ weight of empty petridish $(\mathrm{g})$

$\mathrm{W}=$ weight of fruit sample taken $(\mathrm{g})$

\section{Mucilage content (\%)}

Estimated by the procedure of Woolfe et al., (1977). $25 \mathrm{~g}$ of fresh immature fruit sample was ground in $125 \mathrm{ml}$ of distilled water. It was centrifuged at $4000 \mathrm{rpm}$ for 15 minutes and clear viscous solution was decanted. The solution was then heated at $70^{\circ} \mathrm{C}$ temperature for 5 minutes to inactivate enzymes. The mucilage was precipitated with 3 volumes of ethanol $(75 \mathrm{ml})$ and washed with more ethanol followed by acetone. The cream coloured solid collected on pre-weighed Whatman No. 
1 filter paper was dried under vacuum at $25^{\circ} \mathrm{C}$ for 12 hours.

Mucilage $(\%)=\frac{\mathrm{W}_{2}-\mathrm{W}_{1}}{\mathrm{~W}} \mathrm{------}$ X 100

$\mathrm{W}_{2}=$ weight of filter paper + mucilage solid after drying $(\mathrm{g})$

$\mathrm{W}_{1}=$ weight of filter paper

$\mathrm{W}=$ weight of fruit sample taken $(\mathrm{g})$

\section{Mineral content (mg/kg)}

Estimated as per Ranganna (1986). $2 \mathrm{~g}$ of dried powder fruit sample was added in preweighed empty crucibles. Sample was ignited on heater to remove smoke and then kept in Muffle furnace at $500^{\circ} \mathrm{C}$ for 5 hours. The furnace was switched off and kept overnight. The cooled crucibles were then weighed to estimate mineral content.

Mineral content $(\mathrm{mg} / \mathrm{kg})=\left[\mathrm{W}_{2}-\mathrm{W}_{1} / \mathrm{W}\right] \mathrm{X}[1 /$ 1000]

$\mathrm{W}_{2}=$ weight of empty crucible + weight of ignited sample $(\mathrm{g})$

$\mathrm{W}_{1}=$ weight of empty crucible

$\mathrm{W}=$ weight of dried sample taken $(\mathrm{g})$

\section{Statistical analysis}

The raw data of two successive years (2011 and 2012) were compiled by taking the means of all the plants taken for each treatment and replication for different traits. The data was averaged and the averages were statistically and biometrically analyzed. Analysis of variance was done according to Panse and Sukhatme (1978) for each character. Genotypic and phenotypic variances, genotypic coefficient of variation (GCV) and phenotypic coefficient of variation (PCV), heritability $\left(h_{\mathrm{b}}^{2}\right)$ in broad sense and genetic advance in percent of mean were estimated according to Robinson (1966). Correlation among the traits was analyzed following Johnson et al., (1955).

\section{Results and Discussion}

The combined mean performance, coefficient of variation ( $\mathrm{CV} \%)$ and critical difference (CD) for quantitative and quality traits of 37 okra genotypes are presented in Table 1 . The analysis of variance revealed significant differences among genotypes for all the traits studied except harvest duration, indicating the validity for further statistical analysis.

\section{Combined mean performance of okra genotypes}

Komal took least days to $50 \%$ emergence (13.67). Days to $50 \%$ flowering was least in (P-8 X AA)-7-1-1-1 (48.33) and highest in (IC-31033-1 X P-8)-2-2-1-2 (55.00). Barkha Bahar took less days to first picking (53.33 days). SKBS-11 had highest plant height of $278 \mathrm{~cm}$. Among fruit yield traits, highest fruit yield per plant (251.33 g) was observed in (VRH-2XVRO-6)-1-1-2-1 followed by Hissar Unnat (246 g). Number of fruits per plant were highest in (IC-169469-1XPK)-1-2-1-2 (17.33). Kanchan had least average fruit weight of $12.50 \mathrm{~g}$ and highest in (IC-310331XAA)-5-1-1-1 (20.09 g). High number of nodes (19.33) and least internodal length (11.07) was observed in (IC-169469-1 X PK)1-2-1-2. Fruit length $(16.86 \mathrm{~cm})$ and fruit diameter $(2.01 \mathrm{~cm})$ was highest in (IC-310331XP-8)-8-1-1-1 and Barkha Bahar respectively.

Among quality traits, dry matter content was least $(2.87 \%)$ in (IC-31033-1XAA)-7-1-1-1 and mucilage percentage was highest $(0.96 \%)$ 
in (IC-31033-1-AA)-5-1-1-1. (IC-310331XAA)-3-1-1-1 recorded highest mineral content $17.72 \%$.

Estimates of genetic parameters of variability for different quantitative and quality traits

The coefficients of variation (GCV, PCV), broad sense heritability $\left(\mathrm{h}^{2} \mathrm{~b}\right)$, and genetic advance (\%) of mean are presented in Table 2. Categorization of PCV, GCV, Heritability and genetic advance into low, medium and high values was also shown in Table 3 .

GCV values ranged from 1.35 (days to first picking) to $54.14 \%$ (mucilage \%). The highest genotypic variance was for quality traits as compared to quantitative traits such as mucilage content (54.14) followed by mineral content (45.87) and dry matter (34.28). Internodal length (16.79) and first fruit producing node (16.52) exhibited moderate genotypic variances.

On the other hand, the lowest genotypic variance was observed for plant height (13.67) followed by fruit diameter (10.14), fruits/plant (9.02), fruit yield/plant (8.91), nodes/plant (8.19), fruit length (7.94), average fruit weight (7.58), days to $50 \%$ emergence (3.83), days to $50 \%$ flowering (2.38) and days to first picking (1.35).

The phenotypic variances for all the traits were slightly higher but close to the genotypic variances. PCV is also high for all the quality traits. The PCV values showed similar trends as GCV values and ranged from $2.64 \%$ (days to first picking) to $55.83 \%$ (mucilage $\%$ ).

The heritability estimates ranged from 19\% (first fruit producing node) to $94 \%$ (mucilage $\%$ ). High heritability coupled with high genetic advance was shown by internodal length, mucilage and mineral content.
Highest expected genetic advance was exhibited for mucilage (109.01\%) followed by mineral content $(95.14 \%)$, dry matter $(61.95 \%)$ and internodal length (33.26\%) respectively. Moderate genetic advance was found in plant height (24.91\%).

\section{Correlation studies}

Phenotypic and genotypic correlation estimation was estimated on accessions from sixteen characters of okra and presented in Table 4. The results show that estimates of genotypic correlation coefficients were generally higher than their corresponding phenotypic correlation coefficients for most of the quantitative and quality traits, indicating strong inherent association among such traits, but the phenotypic expression of the correlation gets reduced under the influence of the environment.

Fruit yield per plant was significantly and positively associated with most of the characters except days to $50 \%$ flowering, days to first picking, first fruit producing node, internodal length, fruit diameter and quality traits viz., dry matter, mucilage percentage and mineral content, both at genotypic and phenotypic level.

At both genotypic and phenotypic level, strong positive and significant associations of fruits/plant, average fruit weight and nodes per plant were recorded with fruit yield/plant. Similarly plant height $(0.756,0.812)$ and average fruit weight $(0.442,0.552)$ showed positive and significant correlation with internodal length. Internodal length also showed significant and positive correlation with fruit diameter $(0.218,0.237)$. Positive and significant correlations were also showed by fruits/plant with nodes/plant $(0.852,1.081)$; plant height with average fruit weight $(0.251$, 0.345 ); days to $50 \%$ flowering with days to first picking $(0.589,0.922)$ respectively. 
Table.1 Combined mean performance, coefficient of variation (CV) and critical difference (CD) values for quantitative and quality traits in okra (2011-2012)

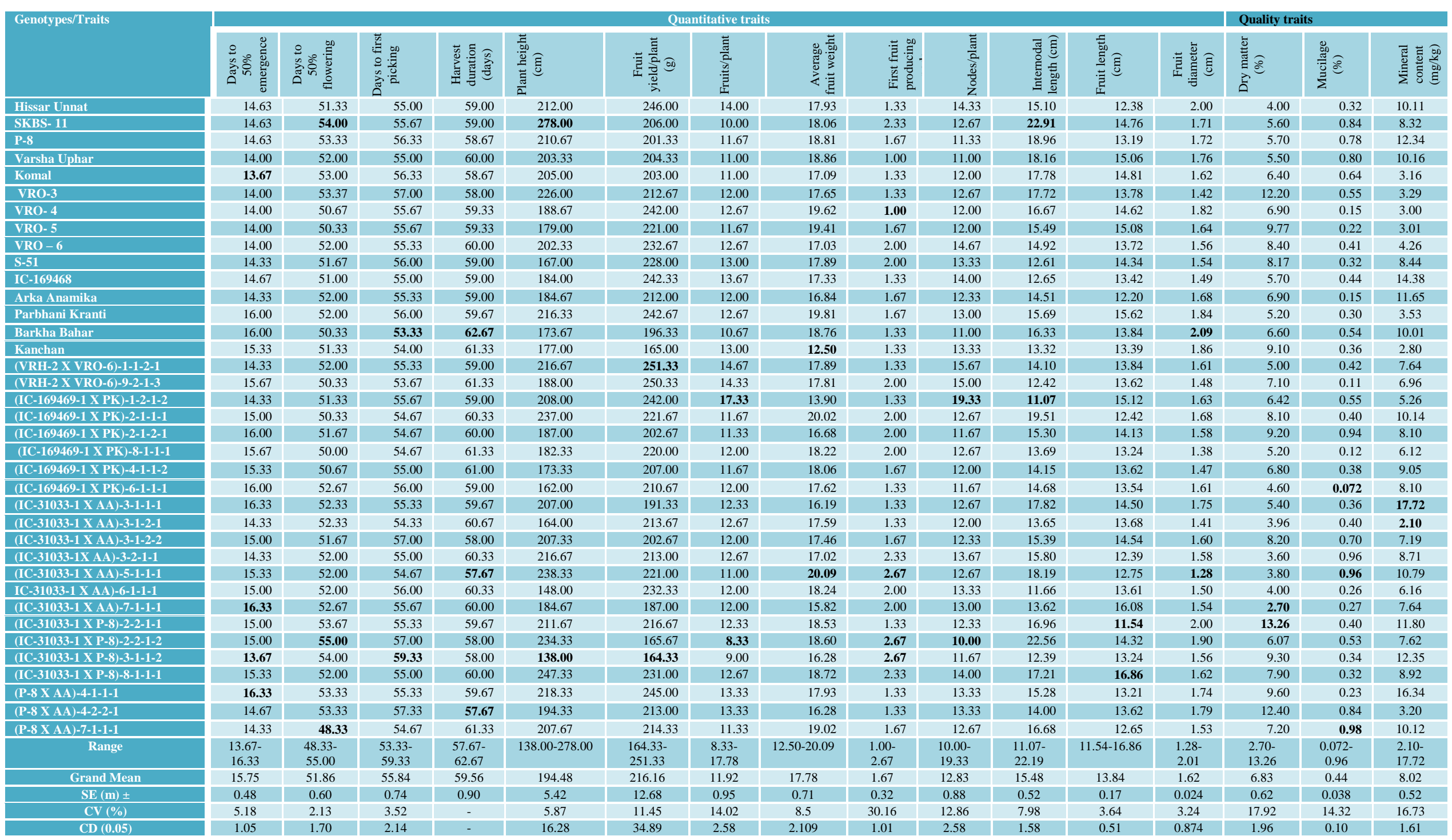


Table.2 Estimates of genetic parameters of variability for different quantitative and Quality traits in okra

\begin{tabular}{|c|c|c|c|c|c|c|}
\hline \multirow{2}{*}{$\begin{array}{l}\text { Sr. } \\
\text { No. }\end{array}$} & \multirow[t]{2}{*}{ Traits } & \multicolumn{3}{|c|}{ Coefficient of Variation } & \multirow{2}{*}{$\begin{array}{l}\text { Heritability } \\
\left(\mathbf{h}^{2}\right)(\%)\end{array}$} & \multirow{2}{*}{$\begin{array}{c}\text { Genetic } \\
\text { advance ( } \%) \\
\text { of mean }\end{array}$} \\
\hline & & $\begin{array}{l}\text { Phenotypic } \\
\text { (PCV) }\end{array}$ & $\begin{array}{l}\text { Genotypic } \\
\text { (GCV) }\end{array}$ & $\begin{array}{l}\text { Environmental } \\
\text { (ECV) }\end{array}$ & & \\
\hline I. & \multicolumn{6}{|c|}{ Quantitative traits } \\
\hline & Days to $50 \%$ emergence & 6.51 & 3.83 & 5.14 & 33 & 5.12 \\
\hline & Days to $50 \%$ flowering & 3.27 & 2.38 & 2.13 & 56 & 3.77 \\
\hline & Days to first picking & 2.64 & 1.35 & 2.30 & 29 & 1.39 \\
\hline & Harvest duration (days) & - & - & - & - & - \\
\hline & Plant height $(\mathrm{cm})$ & 14.19 & 13.67 & 4.29 & 87 & 24.91 \\
\hline & Fruit yield/plant (g) & 12.58 & 8.91 & 10.43 & 47 & 13.78 \\
\hline & Fruits/plant & 16.13 & 9.02 & 13.49 & 34 & 11.62 \\
\hline & Average fruit weight $(\mathrm{g})$ & 10.36 & 7.58 & 7.68 & 54 & 12.49 \\
\hline & First fruit producing node & 40.16 & 16.52 & 36.09 & 19 & 14.13 \\
\hline & Nodes/plant & 14.81 & 8.19 & 12.03 & 33 & 9.25 \\
\hline & Internodal length $(\mathrm{cm})$ & 17.97 & 16.79 & 6.85 & 86 & 33.26 \\
\hline & Fruit length $(\mathrm{cm})$ & 8.31 & 7.94 & 2.69 & 93 & 16.32 \\
\hline & Fruit diameter $(\mathrm{cm})$ & 10.29 & 10.14 & 2.72 & 91 & 18.99 \\
\hline II. & \multicolumn{6}{|c|}{ Quality traits } \\
\hline & Dry matter $(\%)$ & 38.87 & 34.28 & 17.54 & 78 & 61.95 \\
\hline & Mucilage (\%) & 55.83 & 54.14 & 14.93 & 94 & 109.01 \\
\hline & Mineral content $(\mathrm{mg} / \mathrm{kg})$ & 48.27 & 45.87 & 12.58 & 92 & 95.14 \\
\hline
\end{tabular}

Table.3 Estimates of PCV, GCV, Heritability and Genetic advance

\begin{tabular}{|c|c|c|c|c|c|}
\hline S. No & Traits & PCV & GCV & Heritability & Genetic Advance \\
\hline \multirow[t]{14}{*}{ I. } & Quantitative traits & & & & \\
\hline & Days to $50 \%$ emergence & $\mathrm{L}$ & $\mathrm{L}$ & $\mathrm{L}$ & $\mathrm{L}$ \\
\hline & Days to $50 \%$ flowering & $\mathrm{L}$ & $\mathrm{L}$ & M & $\mathrm{L}$ \\
\hline & Days to first picking & $\mathrm{L}$ & $\mathrm{L}$ & $\mathrm{L}$ & $\mathrm{L}$ \\
\hline & Harvest Duration & & & & \\
\hline & Plant height $(\mathrm{cm})$ & $\mathrm{L}$ & $\mathrm{L}$ & $\mathrm{H}$ & M \\
\hline & Fruit yield/plant (g) & $\mathrm{L}$ & $\mathrm{L}$ & $\mathrm{L}$ & $\mathrm{L}$ \\
\hline & Fruits/plant & M & $\mathrm{L}$ & $\mathrm{L}$ & $\mathrm{L}$ \\
\hline & Average fruit weight $(\mathrm{g})$ & $\mathrm{L}$ & $\mathrm{L}$ & M & $\mathrm{L}$ \\
\hline & First fruit producing node & $\mathrm{H}$ & M & $\mathrm{L}$ & $\mathrm{L}$ \\
\hline & Nodes/plant & M & $\mathrm{L}$ & $\mathrm{L}$ & $\mathrm{L}$ \\
\hline & Internodal length $(\mathrm{cm})$ & M & M & $\mathrm{H}$ & $\mathrm{H}$ \\
\hline & Fruit length(cm) & $\mathrm{L}$ & $\mathrm{L}$ & $\mathrm{H}$ & $\mathrm{L}$ \\
\hline & Fruit diameter $(\mathrm{cm})$ & $\mathrm{L}$ & $\mathrm{L}$ & $\mathrm{H}$ & $\mathrm{L}$ \\
\hline \multirow[t]{4}{*}{ II. } & Quality traits & & & & \\
\hline & Dry matter $(\%)$ & $\mathrm{H}$ & $\mathrm{H}$ & M & $\mathrm{H}$ \\
\hline & Mucilage (\%) & $\mathrm{H}$ & $\mathrm{H}$ & $\mathrm{H}$ & $\mathrm{H}$ \\
\hline & Mineral content $(\mathrm{mg} / \mathrm{kg})$ & $\mathrm{H}$ & $\mathrm{H}$ & $\mathrm{H}$ & $\mathrm{H}$ \\
\hline
\end{tabular}

L-Low; M-Medium; H-High 
Table.4 Estimates of correlation coefficients at the phenotypic (P) and genotypic (G) levels for quantitative and quality traits in okra

\begin{tabular}{|c|c|c|c|c|c|c|c|c|c|c|c|c|c|c|c|c|c|}
\hline \multirow[t]{2}{*}{ Traits } & & \multicolumn{12}{|c|}{ Quantitative trait } & \multicolumn{4}{|c|}{ Quality traits } \\
\hline & & 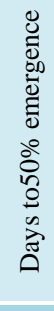 & 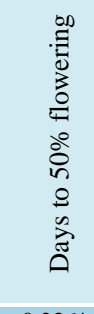 & 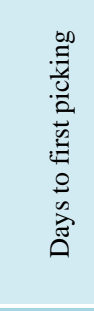 & 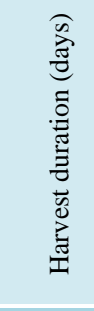 & 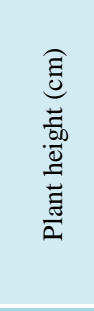 & 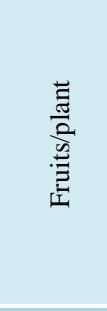 & 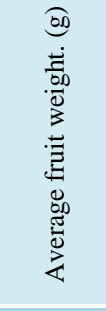 & 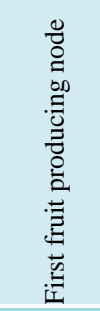 & 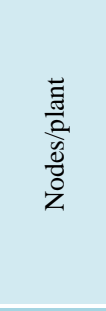 & 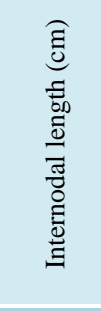 & 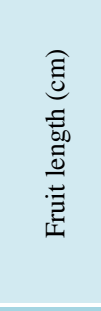 & 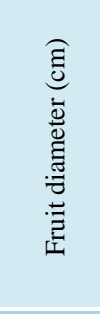 & 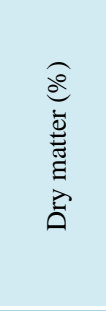 & 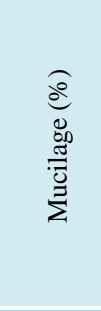 & 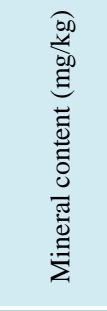 & 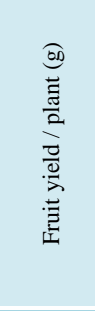 \\
\hline \multirow[t]{2}{*}{ Days to $50 \%$ emergence } & $\mathrm{P}$ & & $-0.236^{*}$ & $-0.218^{*}$ & 0.154 & -0.0041 & 0.0272 & 0.0626 & 0.0882 & 0.0586 & -0.0021 & 0.121 & 0.0670 & -0.0844 & $-0.192 *$ & $0.214^{*}$ & 0.117 \\
\hline & G & & $-0.321 *$ & -0.765 & $0.635^{*}$ & -0.0723 & -0.0989 & 0.171 & 0.0541 & -0.132 & -0.0569 & 0.125 & 0.114 & $-0.245^{*}$ & $-0.278 *$ & $0.342 *$ & 0.0590 \\
\hline \multirow{2}{*}{ Days to $50 \%$ flowering } & $\mathrm{P}$ & & & $0.589^{*}$ & $-0.566^{*}$ & 0.149 & -0.0642 & -0.169 & 0.100 & -0.0472 & 0.187 & 0.0892 & 0.151 & 0.136 & 0.121 & 0.0311 & $-0.239 *$ \\
\hline & G & & & $0.922 *$ & $-1.036^{*}$ & $0.205^{*}$ & $-0.234 *$ & $-0.248 *$ & $0.312 *$ & -0.129 & $0.264^{*}$ & 0.160 & $0.194 *$ & 0.152 & 0.132 & 0.0958 & $-0.461 *$ \\
\hline \multirow[t]{2}{*}{ Days to first picking } & $\mathrm{P}$ & & & & $-0.778 *$ & 0.0441 & -0.179 & -0.0169 & 0.152 & -0.178 & 0.0769 & -0.0139 & 0.0516 & $0.242 *$ & 0.0871 & -0.0553 & $-0.236^{*}$ \\
\hline & G & & & & $-0.876^{*}$ & 0.0363 & -0.0639 & $-0.291^{*}$ & 0.0392 & 0.0710 & 0.128 & 0.178 & 0.051 & $0.439^{*}$ & 0.169 & -0.0152 & $-0.273^{*}$ \\
\hline \multirow[t]{2}{*}{ Harvest duration (days) } & $\mathrm{P}$ & & & & & -0.169 & 0.132 & -0.0811 & $-0.212 *$ & 0.102 & -0.149 & 0.0080 & -0.0280 & -0.119 & -0.152 & 0.0010 & 0.118 \\
\hline & $\mathrm{G}$ & & & & & $-0.381 *$ & -0.0016 & 0.155 & 0.134 & -0.152 & $-0.387 *$ & $-0.192 *$ & 0.0079 & $-0.308^{*}$ & $-0.348 *$ & -0.109 & 0.0974 \\
\hline \multirow{2}{*}{ Plant height (cm) } & $P$ & & & & & & -0.056 & $0.251^{*}$ & 0.122 & 0.0192 & $0.756^{*}$ & 0.0851 & 0.168 & 0.0163 & $0.367 *$ & 0.122 & 0.122 \\
\hline & G & & & & & & -0.0672 & $0.345^{*}$ & $0.452 *$ & 0.112 & $0.812^{*}$ & 0.112 & 0.178 & 0.0057 & $0.396^{*}$ & 0.134 & 0.194 \\
\hline \multirow{2}{*}{ Fruits/plant } & $\mathrm{P}$ & & & & & & & $-0.532^{*}$ & $-0.329 *$ & $0.852^{*}$ & $-0.510 *$ & 0.140 & -0.0649 & -0.0429 & -0.141 & -0.152 & $0.722 *$ \\
\hline & G & & & & & & & $-0.422^{*}$ & $-0.456^{*}$ & $1.089^{*}$ & $-0.759^{*}$ & 0.0089 & 0.0153 & 0.0300 & $-0.252 *$ & $-0.268^{*}$ & $0.582^{*}$ \\
\hline \multirow[t]{2}{*}{ Average fruit weight (g) } & $\mathrm{P}$ & & & & & & & & 0.0852 & $-0.478^{*}$ & $0.442 *$ & -0.0527 & -0.0187 & -0.0912 & 0.0172 & 0.123 & $0.211^{*}$ \\
\hline & G & & & & & & & & $0.245^{*}$ & $-0.419^{*}$ & $0.552^{*}$ & -0.088 & -0.0231 & -0.181 & 0.0541 & 0.178 & $0.482^{*}$ \\
\hline \multirow[t]{2}{*}{ First fruit producing node } & $\mathrm{P}$ & & & & & & & & & -0.0015 & 0.122 & -0.123 & -0.142 & -0.0882 & 0.131 & 0.120 & $-0.321 *$ \\
\hline & G & & & & & & & & & -0.126 & $0.426^{*}$ & -0.186 & $-0.514 *$ & $-0.391^{*}$ & $0.266^{*}$ & $0.255^{*}$ & $-0.229 *$ \\
\hline \multirow[t]{2}{*}{ Nodes/plant } & $\mathrm{P}$ & & & & & & & & & & $-0.487 *$ & 0.106 & -0.108 & -0.0399 & -0.0892 & -0.0971 & $0.582^{*}$ \\
\hline & G & & & & & & & & & & $-0.656^{*}$ & -0.0172 & -0.109 & -0.0472 & -0.183 & -0.187 & $0.639^{*}$ \\
\hline \multirow[t]{2}{*}{ Internodal length (cm) } & $\mathrm{P}$ & & & & & & & & & & & 0.074 & $0.218^{*}$ & 0.0167 & $0.376^{*}$ & 0.169 & $-0.241 *$ \\
\hline & G & & & & & & & & & & & 0.0882 & $0.237 *$ & 0.0181 & $0.429 *$ & 0.194 & $-0.312 *$ \\
\hline \multirow[t]{2}{*}{ Fruit length $(\mathbf{c m})$} & $\mathrm{P}$ & & & & & & & & & & & & -0.0452 & -0.173 & -0.0692 & $-0.329 *$ & 0.0982 \\
\hline & G & & & & & & & & & & & & -0.0028 & -0.188 & -0.0659 & $-0.372 *$ & -0.0763 \\
\hline \multirow[t]{2}{*}{ Fruit diameter $(\mathrm{cm})$} & $\mathrm{P}$ & & & & & & & & & & & & & 0.137 & -0.0901 & $0.255^{*}$ & -0.0975 \\
\hline & G & & & & & & & & & & & & & 0.141 & -0.112 & $0.271^{*}$ & -0.0120 \\
\hline \multirow[t]{2}{*}{ Dry matter $(\%)$} & $\mathrm{P}$ & & & & & & & & & & & & & & 0.0228 & -0.0886 & -0.119 \\
\hline & G & & & & & & & & & & & & & & 0.0289 & -0.0899 & -0.142 \\
\hline \multirow[t]{2}{*}{ Mucilage (\%) } & $\mathrm{P}$ & & & & & & & & & & & & & & & 0.0321 & -0.177 \\
\hline & G & & & & & & & & & & & & & & & 0.0592 & $-0.249 *$ \\
\hline \multirow[t]{2}{*}{ Mineral content (mg/kg) } & $\mathrm{P}$ & & & & & & & & & & & & & & & & -0.0535 \\
\hline & $\mathrm{G}$ & & & & & & & & & & & & & & & & -0.091 \\
\hline Fruit yield/plant (g) & $\begin{array}{l}P \\
G\end{array}$ & & & & & & & & & & & & & & & & \\
\hline
\end{tabular}


More significant genotypic association between different pairs of characters than the phenotypic correlation means that there is strong association between those characters genetically, but the phenotypic value is lessened by the significant interaction of environment. Among quality traits, days to $50 \%$ emergence $(0.214,0.342)$ and fruit diameter $(0.255,0.271)$ showed positive and significant correlation with mineral content; days to first picking with dry matter $(0.242$, $0.439)$; plant height $(0.367,0.396)$ and internodal length $(0.376,0.429)$ with mucilage percentage which acts as potential selection criteria in breeding programs aiming at higher yield.

On the contrary, days to $50 \%$ flowering ($0.239,-0.461)$, days to first picking $(-0.236$, $0.273)$, first fruit producing node $(-0.321$, $0.229)$, internodal length $(-0.241,-0.312)$ indicated strong negative and significant correlations with fruit yield/plant. Similar associations was also observed between days to $50 \%$ flowering $(-0.566,-1.036)$ and days to first picking $(-0.778,-0.876)$ with harvest duration; fruits/plant with first fruit producing node $(-0.329,-0.456)$ and internodal length ($0.510,-0.759)$; average fruit weight with nodes/plant $(-0.478,-0.417)$; nodes/plant with internodal length $(-0.487,-0.656)$. Among quality traits, negative and significant association was shown by days to $50 \%$ emergence with mucilage content (-0.192, 0.278 ) and fruit length with mineral content ($0.329,-0.372)$, respectively.

Variability plays a vital role for the selection of superior genotypes in crop improvement programs. Agronomic traits are quantitative in nature, and interact with environment under study, so partitioning the traits into genotypic, phenotypic, and environmental effects is necessary to find out the additive or heritable portion of variability. ANOVA revealed remarkable variation in all the traits under investigation. Several research findings are available dealing with the varietal variation in okra with respect to many characters by Sindhumole and Manju (2014), Singh et al., (2014) and Zhu et al., (2018).

In the present investigation PCV was higher than GCV among all the characters studied. The difference between PCV and GCV is probably due to the environmental conditions available during experiment (Sarker et al., 2015). Variation for number of fruits per plant, average fruit length and average fruit weight was found to be quite high which might be responsible for the wide range in yield potential of different genotypes. Similar variation for days to marketable maturity in okra was also reported by Nwangburuka et al., (2011), Koundinya et al., (2013) and Chandra et al., (2014). The variability observed among the genotypes shows that there are potentials for improvement in okra. Promising genotypes such as Hissar Unnat, VRO-4 and among accessions (VRH2XVRO-6)-1-1-2-1, (VRH-2XVRO-6)-9-2-13 may be considered for further improvement just as the diversity among the genotypes could be explored through hybridization.

Variability alone is not of much help in determining the heritable portion of variation.

The amount of gain expected from a selection depends on heritability and genetic advance in a trait. Heritability has been widely used to assess the degree to which a character may be transmitted from parent to offspring. Knowledge of heritability of a character is important as it indicates the possibility and extent to which improvement is possible through selection (Robinson et al., 1949). However, high heritability alone is not enough to make sufficient improvement through selection generally in advance generations unless accompanied by substantial amount of genetic advance 
(Johnson et al., 1955). The expected genetic advance is a function of selection intensity, phenotypic variance and heritability and measures the differences between the mean genotypic values of the original population from which the progeny is selected. There was high heritability estimates for quality traits as compared to quantitative traits. Mucilage, mineral content, plant height, fruit diameter, fruit length and internodal length showed high heritability. This suggests that the genotypic factor had greater effect on phenotypic performance of these traits. Hence selection based on the phenotypic performance of these characters will be reliable and effective. It has been emphasized that genetic gain should be considered along with heritability in coherent selection breeding program (Shukla et al., 2006).

High heritability coupled with high genetic advance was also shown by internodal length, mucilage and mineral content; these characters could be explained by additive gene action, hence their improvement can be done through mass selection. This agrees with the findings of Ibrahim and Hussein (2006), Goswami et al., (2014), Kumar et al., (2012) and Singh et al., (2017). Similarly high to medium heritability coupled with medium to low genetic advance was shown by plant height, fruit length, fruit diameter and dry matter. These traits are governed by nonadditive gene action, which limits the scope for improvement through selection, whereas if it is governed by additive gene action, heritability and genetic advance would be high, consequently substantial gain can be achieved through selection (Sarker et al., 2015).

The higher genotypic correlation coefficients observed in almost all the characters suggests very strong inherent association between various characters at genetic level. This is similar to the report of Ibrahim and Hussein
(2006) in Hibiscus sabdariffa L.). In the present study fruit yield per plant had significant positive correlation with fruits per plant, average fruit weight as well as nodes per plant at both phenotypic and genotypic level respectively, indicating that fruit yield/plant in okra could be increased with the increase of fruits/plant, average fruit weight and nodes per plant. The present findings are in conformity with those of Khan et al., (2005), Adiger et al., (2011), Jagan et al., (2013), Reddy et al., (2013) and Mishra et al., (2015), Nwangburuka et al., (2012) and Sarker et al., (2015).

However, negative correlation at the phenotypic and genotypic level between fruit yield per plant and days to $50 \%$ flowering, days to first picking, first fruit producing node and internodal length suggests that any selection to improve okra fruit yield directed towards the phenotype of these characters will not be effective and also suggests the influence of environmental factors limiting the yield. The result agrees with the report of Simon et al., (2013) and Mishra et al., (2015).

Considering high genotypic and phenotypic variances along with GCV and PCV values, moderate to high heritability coupled with genetic advance as percent of mean, seven traits (plant height, internodal length, fruit length, fruit diameter, dry matter, mucilage and mineral content) could be selected for the improvement of okra genotypes under study. However, the correlation study revealed strong positive association of fruits/plant, average fruit weight and nodes per plant with fruit yield/plant. Selection based on fruits/plant, average fruit weight and nodes/plant could lead to increase the fruit yield of okra genotypes. Based on mean performance of these genotypes, four okra genotypes (VRH-2 X VRO-6)-1-1-2-1, (VRH-2 X VRO-6)-9-2-1-3, (IC-169469-1 X PK)-1-2-1-2 and Hissar Unnat were identified 
as high yielding having substantial dry matter, mucilage and mineral content.

\section{Acknowledgements}

Sincere gratitude goes to the Administration of CSK Himachal Pradesh Agricultural University, Palampur for funding of this project. The support of staff of Department of Vegetable Science and Floriculture is highly appreciated.

\section{References}

Adiger S, Shanthakumar G, Gangashetty P I, Salimath PM, 2011. Association studies in okra (Abelmoschus esculentus (L.) Moench). Electronic J. Plant Breed., 2(4): 568-573

Arora D, Kumar S, Ghai TR, 2008. Gene action for some biochemical traits in okra (Abelmoschus esculentus (L.) Moench). Veg. Sci., 35: 519-529

Asish K, Manivannan N, Varman PV, 2008. Character association and path analysis in sunflower. Madras Agric. J., 95(712):425-428

Chandra S, Bhardwaj ML, Kumar R, Kumar D, Kumar S, Gautam N, Dogra B, Sharma S, 2014. Estimation of parameters of variability for different quantitative traits in okra, Abelmoschus esculentus (L) Moench. Int. J. Farm Sci., 4(3): 33-41

Goswami A, Singh B, Singh A, 2014. Study of genetic variability, heritability and genetic advance in okra (Abelmoschus esculentus (L.) Moench). Prog. Agric., 14(1): 57-62

Ibrahim MM, Hussein RM, 2006. Variability, heritability and genetic advance in some genotypes of roselle (Hibiscus sabdariffa L.). World J. Agric. Sci., 2(3): 340-345

Jagan K, Reddy KR, Sujatha M, Sravanthi V, Reddy SM, 2013. Studies on genetic variability, heritability and genetic advance in okra (Abelmoschus esculentus (L.) Moench). IOSR J. Agric. Vet. Sci. 5(1): 59-61

Johnson HW, Robinson HF, Comstock RE, 1955. Estimates of genetic and environmental variability in soybean. Agron. J., 47: 314-318

Khan SH, Ahmed N, Jabeen N, 2005. Variability and correlation studies in okra (Abelmoschus esculentus (L.) Moench). J. Res., 4(2): 179-183

Kiran Patro TS, Ravisankar C, 2004. Genetic variability and multivariate analysis in okra [Abelmoschus esculentus (L.) Moench]. Trop. Agric. Res., 16: 99-113

Koundinya AVV, Dhankhar SK, Yadav AC, 2013. Genetic variability and divergence in okra (Abelmoschus esculentus (L) Moench). Indian J. Agric. Sci., 83(6): 685-688

Kumar P, Singh KV, Singh B, Kumar S, Singh O, 2012. Genetic variability, heritability and genetic advance in okra [Abelmoschus esculentus (L.) Moench]. Annals horti., 5(1): 69-73

Mishra A, Mishra HN, Senapati N, Tripathy $\mathrm{P}$, 2015. Genetic variability and correlation studies in Okra (Abelmoschus esculentus (L.) Moench). Electronic J. Plant Breed., 6(3)-866869

Nwangburuka CC, Denton OA, Kehinde OB, Ojo DK, Popoola AR, 2012. Genetic variability and heritability in cultivated okra [(Abelmoschus esculentus (L.) Moench]. Spanish J. Agric. Res., 10 (1): 123-129

Nwangburuka CC, Kehinde OB, Ojo DK, Denton OA, Popoola AR, 2011. Morphological classification of genetic diversity in cultivated okra, Abelmoschus esculentus (L.) Moench using principal component analysis (PCA) and single linkage cluster 
analysis (SLCA). African J. Biotech., 10(54): 11165-11172

Panse VG, Sukhatme PV, 1978. Statistical methods for agricultural workers. ICAR, New Delhi. 347 pp.

Ranganna S, 1986. Handbook of analysis and quality control for fruit and vegetable products. Tata Mc Graw- Hill, New Delhi. p 141.

Reddy T, Babu H, Ganesh M, Reddy C, Begum H, Reddy R, Babu DJ, 2013. Correlation and path coefficient analysis of quantitative characters in okra (Abelmoschus esculentus (L.) Moench). Songklanakarin J. Sci. Technology, 35(3): 243-250

Robinson HF, Comstock RE, Harvey PH, 1949. Estimates of heritability and the degree of dominance in corn. Agron. J., 41: 353-359

Robinson, HF, 1966. Quantitative genetics in relation to breeding and impact of mendelism in agriculture, botany and medicine. Indian J. Gene., 26:171-187

Sarker U, Islam MT, Rabbani MG, Oba S, 2015. Variability, heritability and genetic association in vegetable amaranth (Amaranthus tricolor L.). Spanish J. Agri. Res., 13(2): e0702

Shukla S, Bhargava A, Chatterjee A, Srivastava J, Singh N, Singh SP, 2006. Mineral profile and variability in vegetable amaranth (Amaranthus tricolor). Plant Food Human Nutrition, 61: 23-28

Simon SY, Gashua IB, Musa I, 2013. Genetic variability and trait correlation studies in okra [Abelmoschus esculentus (L.) Moench]. Agric. Biol. J. North America, 4(5): 532-538

Sindhumole P, Manju P, 2014. Evaluation of okra [Abelmoschus esculentus (L.) Moench] germplasm for yield and quality of fruits. Indian J. Plant Genet. Resour., 27(1): 28-35

Singh P, Jain PK and Sharma A. 2017. genetic variability, heritability and genetic advance in chilli (Capsicum annum L.) genotypes. Int. J. Curr. Microbiol. App. Sci., 6(9): 2704-2709

Singh SK, Sachan CP, Singh B, 2014. Genetic variability and relative contribution of component characters on yield of okra. Annals Horti., 7 (2): 189-192

Tindall HD, 1983. Vegetables in the tropics. MacMillan Press Ltd., London

Woolfe ML, Chaplin MF, Otchere G, 1977. Studies on the mucilages extracted from okra fruits (Abelmoschus esculentus (L.) Moench) and Baobab leaves (Adansonia digitata). J. Sci. Fed. Agri., 28: 519-529

Zhu S, Zhang S, Liu Q, Luo T, Tang Z and Zhou Y. 2018. Phenotypic variation and diversity of cauliflower (Brassica oleracea Var. Botrytis) inbred lines. Int. J. Agri. Bio., 20: 1041-1048

\section{How to cite this article:}

Sonia Sood, Nivedita Gupta and Deepti Sharma. 2018. Genetic Variation Patterns for the Selection of Elite Genotypes in Cultivated Okra (Abelmoschus esculentus (L.) Moench). Int.J.Curr.Microbiol.App.Sci. 7(09): 1764-1775. doi: https://doi.org/10.20546/ijcmas.2018.709.213 